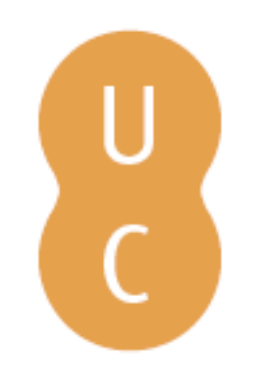

pommalina

\title{
Nutrient dynamics in the intertidal pools of the Mondego estuary: IV - possible contribution to dissolved inorganic phosphorus loading
}
Autor(es):
Lillebo, Ana Isabel; Pardal, Miguel Ângelo; Flindt, Mogens René; Neto, João Magalhães; Macedo, Filomena; Martins, Irene; Marques, João Carlos

Publicado por: Imprensa da Universidade de Coimbra

URL persistente:

URI:http://hdl.handle.net/10316.2/32684

DOI:

DOI:http://dx.doi.org/10.14195/978-989-26-0336-0_18

Accessed : $\quad$ 26-Apr-2023 09:24:29

A navegação consulta e descarregamento dos títulos inseridos nas Bibliotecas Digitais UC Digitalis, UC Pombalina e UC Impactum, pressupõem a aceitação plena e sem reservas dos Termos e Condições de Uso destas Bibliotecas Digitais, disponíveis em https://digitalis.uc.pt/pt-pt/termos.

Conforme exposto nos referidos Termos e Condições de Uso, o descarregamento de títulos de acesso restrito requer uma licença válida de autorização devendo o utilizador aceder ao(s) documento(s) a partir de um endereço de IP da instituição detentora da supramencionada licença.

Ao utilizador é apenas permitido o descarregamento para uso pessoal, pelo que o emprego do(s) título(s) descarregado(s) para outro fim, designadamente comercial, carece de autorização do respetivo autor ou editor da obra.

Na medida em que todas as obras da UC Digitalis se encontram protegidas pelo Código do Direito de Autor e Direitos Conexos e demais legislação aplicável, toda a cópia, parcial ou total, deste documento, nos casos em que é legalmente admitida, deverá conter ou fazer-se acompanhar por este aviso.

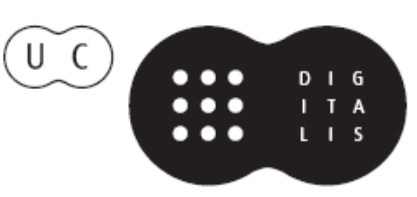


MIGUEL ÂNGELO PARDAL JOÄO CARLOS MARQUES MANUEL AUGUSTO GRAÇA Scientific Editors

\section{Aquatic Ecology of the Mondego River Basin Global Importance of Local Experience}




\author{
MIGUEL ÂNGELO PARDAL \\ JOẢO CARLOS MARQUES \\ MANUEL AUGUSTO GRAÇA \\ Scientific Editors
}

\title{
Aquatic Ecology of the Mondego River Basin Global Importance of Local Experience
}




COORDENAÇÃO EDITORIAL
Imprensa da Universidade de Coimbra
CONCEPÇÃO GRAFICA
António Barros
INFOGRAFIA
António Resende
Estimulus [design] • Coimbra
EXECUÇÃO GRAFICA
GRAFIASA
ILUSTRAÇÃO DA CAPA
P. P. Cunha e ]. Dinis
ISBN
972-8704-04-6
DEPOSITO LEGAL
I75038/02

(C) JANEIRO 2002, IMPRENSA DA UnIVERSIDADE DE COIMBRA

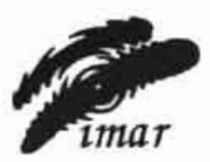

CPIMAR

imar

OBRA PUBLICADA COM O PATROCINIO DE:

IMAR - INSTITUTO DO MAR

IPIMAR - INSTITUTO DE INVESTIGAÇĀO DAS PESCAS E DO MAR 

ANA ISABEL LILLEBØ '

Miguel Ângelo PARdal '

MOGENS RENE FUINDT ${ }^{2}$

João Magalläes neto '

FILOMENA MACEDO ${ }^{3}$

IRENE MaRTins '

JoÃo Carlos Marques '

\author{
NUTRIENT DYNAMICS INTHE INTERTIDAL POOLS \\ OFTHE MONDEGO ESTUARY. \\ IV - POSSIBLE CONTRIBUTIONTO DISSOLVED INORGANIC \\ PHOSPHORUS LOADING
}

\begin{abstract}
In the Mondego estuary, the freshwater from Pranto River represents an important input of phosphorus into the south arm, and the estuary is exporting inorganic dissolved nutrients to the adjoining coastal zone. In fact, a previous study concerning the loading of dissolved inorganic phosphorus showed that the system had a net production of 14 tons (PO-P) $y^{\prime}$.

Results concerning the phosphate efflux rates from intertidal pools level to the water column, evidence the importance of these pools to the internal dissolved inorganic phosphorus loading, especially the muddy bare bottom pools, which showed a clear seasonal variation, with higher efflux in summer. This seasonal variation of phosphate effluxes is also in agreement with previous data concerning the inorganic dissolved phosphate concentrations in the south arm.

The aim of this work was to evaluate the contribution of the efflux of inorganic phosphate from the intertidal pools to the system, and relate it with the export into coastal waters.

At the system level, we considered the seasonal contribution of each type of pool (formed in muddy sediment with and without Spartina cover, and sandy sediment) to the whole system. These preliminary approach shows that the contribution of intertidal pools, and especially in the muddy bare bottom areas which are also the most representative of the system, appears to be very important to the increased concentration of dissolved inorganic phosphorus during summer. Although, this evaluation is quite limited in interpretation, the phosphate efflux from the intertidal pools level seems to have an important contribution to the export of dissolved inorganic phosphorous from the Mondego estuary.

15 MAR - Instituto do Mar. Centro Intendisciplinar de Coimbra a/c Departamento de Zoologia. Universidade de Coimbra. 3004-517 Coimbra. Portugal

is Biological Biological Instutute. SDU - University of Odense. Campusver 55, 5230 Odense M. Denmark

(1) IMAR - Instituto do Mar. Centro de Modelação Ecologica a/c Departamento de Ciências e Engenharia. Faculdade de Ciências e Tecnologia, Universidade Nova de Lisboa, 2825 Monte de Caparica, Portugal
\end{abstract}




\section{Introduction}

Rivers may supply much of the nitrogen and phosphorus into estuaries, but within the estuary, large fractions may be internally recycled through biogeochemical processes. In the south arm of the estuary (Fig. I) water circulation is mainly dependent on tides, and on the freshwater input of a tributary, the Pranto River (Marques et al. 1997. 2002, Pardal et al. 2000, Martins et al. 2001). A sluice controls the Pranto river outflow, and its opening frequency is crucial to the nutrient loading into the estuary (Pardal 1998).

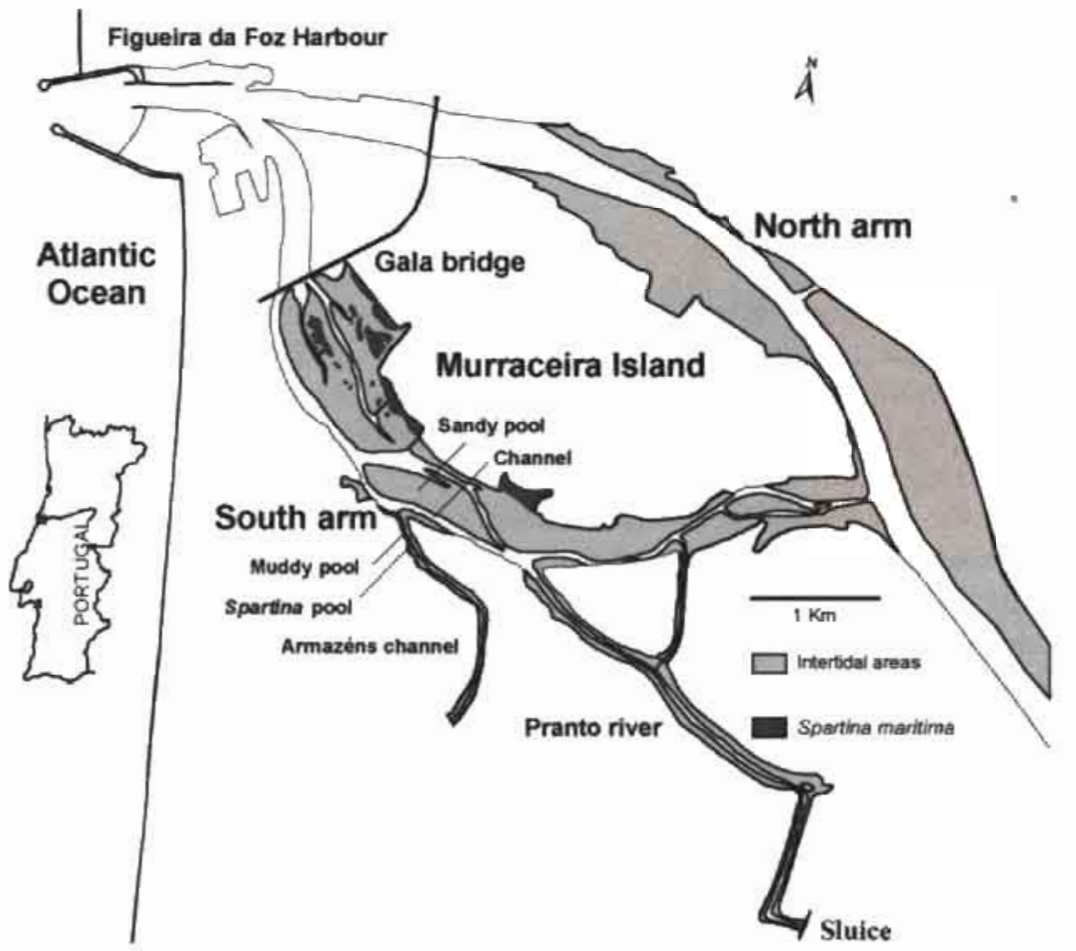

Fig. 1. The Mondego estuary with the location in the south arm of the Pranto River sluice, and the Gala bridge outer boundary.

The study of the close benthic-pelagic coupling of nutrient dynamics and the net losses of nutrients in estuaries requires the description of both transport-dispersion and biogeochemical process, and only proper mass balance calculations can verify whether an area inside the estuary acts as a source or as a sink for nutrients (Flindt et al. 1999. 2002).

An estimate of the nutrient loading into the south arm of the Mondego estuary, carried out between May 1993 and June 1994. showed that dissolved inorganic nutrients were exported from the system (Fig. 2) (Flindt et al. 1997, Pardal 1998). For 


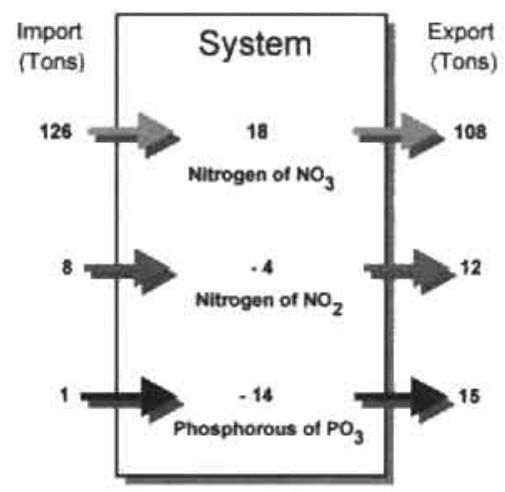

Fig. 2. Nitrogen and Phosphorus annual balance, from June 93 to June 94 , in the south arm of the Mondego estuary.

dissolved inorganic phosphorus, I ton was imported to the system, while 15 tons were exported to the sea (Fig. 2), which means that 14 tons were net released from the south arm of the estuary.

Discharges from the Pranto River sluice are usually higher during winter and early spring, following the seasonal variation of precipitation (Pardal 1998. Martins et al. 2001 ). During this period the system presents low phosphate concentrations in the water column, and increases during late spring and summer, showing a clear interannual seasonal variation. So, most probably phosphorous input from the Pranto River is transported adsorped to particulate matter, and dissolved phosphate in the main water-body results from desorption and mineralisation of phosphate from particulate organic matter (e.g. Pettine et al. 1983. Hinga 1990. Sundby et al. 1992, Valiela 1995. Falcão and Vale 1998. Mitchell and Baldwin 1998).

In the estuarine area, although most of the system is submerged during high tide, when the water level drops in the ebb, intertidal pools formation takes place. A previous study (Lillebø 2002a) showed that in July high temperatures and anoxic conditions, especially durning the night. promoted the phosphate efflux to the overlaying water column. Moreover, results also suggested that these intertidal pools could play a major role to the internal dissolved inorganic phosphorus loading. Therefore we considered necessary to evaluate the contribution of the efflux of phosphate from the intertidal pools level to the main water-body and relate it with phosphorous export into coastal waters.

\section{Material and methods for the existing data}

Loading estimates

In summer the south arm Mondego estuary can be seen almost as a coastal lagoon, with inflow and outflow regimes depending essentially on tides, and on another 
inflow of a small tributary, the Pranto River (See also Marques et al. 2002) (Fig. I). The discharge of the Pranto River changes seasonally as a function of precipitation and the needs for water in the rice fields from the Pranto valley (Martins et al. 200I). A sluice consisting of three sections with $3 \mathrm{~m}$ widths each controls this discharge. The water column height, during discharges, varies between 0.5 and $2.5 \mathrm{~m}$ (Pardal 1998). To avoid salt-water intrusion into the rice fields, discharges take place always during ebb tide (Pardal 1998).

An almost natural downstream boundary of the south arm, where marine water and estuarine water exchange, was considered at the Gala bridge crosssection (Fig. 1). This cross-section is $200 \mathrm{~m}$ width and 2 to $4 \mathrm{~m}$ deep, in high tide situation, with an average depth varying between 2 and $3 \mathrm{~m}$, meaning that during spring ebb tides part of this cross-section may be emerged for short periods (Pardal 1998). The Pranto River sluice was the only upstream input considered, and the downstream cross-section at the Gala bridge was the exchange (outer) boundary. No other inputs were taken into account because they were considered too small to be relevant (Pardal 1998).

The Pranto River discharges and exchanges in the downstream outer boundary were monitored from May 93 to June 94, to quantify the dissolved inorganic phosphorus loading in the south arm of the estuary (Flindt et al. 1997, Pardal 1998). During this period there were 144 discharges from the Pranto River and the monitoring program covered $50 \%$ of them. At Gala bridge outer boundary the monitoring program took place every month, with greater effort when the Pranto sluice was open, covering 18 complete tidal cycles. At both sites water samples were collected with one-hour intervals. Simultaneously, current velocity was measured and salinity and temperature were determined in situ. Water samples were kept frozen until analysis, and dissolved reactive phosphate was quantified according to Strickland and Parson (1968) methodology.

Estimates of total dissolved phosphate inflow were carried out taking into consideration the volume of water discharged during the period the sluice was open, at the Pranto station, and also the tidal regime and wave components at the Gala station. During the discharges, at the Pranto River sluice, current velocity and water height were measure, and the concentration of nutrients quantified. The estimation by simple integration through time of the flow, allowed the calculation of the total water discharged into the estuary, as well as the loading of nutrients discharge at each time the sluice was open (Pardal 1998).

The outer boundary at the Gala bridge is mainly subjected to the physical action of the tidal wave, which is constituted by the overlap of elementary waves. The harmonic components of these elementary waves could be calculated based on continuous measurement during one annual cycle at a sampling station in the same area (Table 1). (Almeida and Seabra Santos 1993 in Pardal 1998). In the referred study (Pardal 1998) it was just considered the waves with amplitude equal or bigger than $4 \%$ of the fundamental harmonic $\mathrm{M}^{2}$ : 
Table I. The harmonic compounds of elementary waves, equal or bigger than $4 \%$ of the fundamental harmonic $M_{2}$ (from Pardal 1998).

\begin{tabular}{|l|c|c|c|c|}
\hline \multirow{2}{*}{ Component } & Period & \multicolumn{2}{|c|}{ Amplitude } & \multirow{2}{*}{ Phase (h) } \\
\cline { 2 - 4 } & $(\mathrm{h})$ & $(\mathrm{m})$ & $\left(\% \mathrm{M}_{2}\right)$ & \\
\hline $\mathrm{M}_{2}$ & 12.421 & 0.910 & 100.0 & 9.785 \\
\hline $\mathrm{S}_{2}$ & 12.000 & 0.333 & 36.6 & 3.620 \\
\hline $\mathrm{N}_{2}$ & 12.658 & 0.200 & 22.0 & 4.127 \\
\hline $\mathrm{O}_{1}$ & 25.819 & 0.067 & 7.4 & 13.216 \\
\hline $\mathrm{K}_{1}$ & 23.934 & 0.065 & 7.2 & 4.009 \\
\hline $\mathrm{L}$ & 12.192 & 0.039 & 4.3 & 7.718 \\
\hline $\mathrm{MS}$ & 354.367 & 0.036 & 4.0 & 201.876 \\
\hline
\end{tabular}

The evolution of the water surface * $(t)$, in the considered section was given by the following equation.

$$
n(t)=\sum_{i=l}^{7} A_{i} \cos \left[\omega_{i}\left(t-\phi_{i}\right)\right]
$$

Where $\mathrm{Ai}{ }^{*} \mathrm{i}$ e *i represent the amplitude, the angular frequency respectively $(=2 * / T)$ and the phase correspondent of each harmonic.

Taking into consideration the small distance of the whole system the wave can be considered a stationary wave whose velocity at time t, is given by the equation:

$$
U(t)=\sum_{i=1}^{7} A_{i} \sqrt{\frac{8}{h_{0}}} \sin \left[\varpi_{i}\left(t-\phi_{i}\right)\right] \sin \left[\varpi_{i} \frac{x_{\beta}-x_{0}}{\sqrt{g h_{0}}}\right]
$$

Where $x_{B}-x_{0}$ represent the distance between Gala bridge and the upstream section $(\approx 4800 \mathrm{~m})$. ho represent the wave height at the outer boundary, creating the forcing, and $g$ the gravitational acceleration (Pardal 1998).

The instantaneous flow was calculated multiplying the signal with the transversal section area, correspondent to the water height in the considered instant The loading of nutrients was estimated by multiplying the flow with the instantaneous concentration measured. Which means that, the difference between tides conditioning the water column height at the Gala cross-section was taken into account (Pardal 1998). This methodology allowed to estimate the loading of dissolved inorganic phosphorous (phosphate) in the south arm of Mondego estuary (Flindt et al. 1997, Pardal 1998),

\section{Long-term field monitoring program}

The variation of nutrient concentration in the water column in the south arm of the estuary has been monitored for several years in order to understand the 
eutrophication process (e.g. Pardal 1998, Martins 2000). This database allowed us to evaluate the seasonal variation of dissolved inorganic nutrients in the system, as well as salinity and temperature. Part of the water analysis was performed according to Stickland and Parson (1968) and others according to Standard Methods (1995).

Inorganic phosphate dynamics in intertidal pools

Within the downstream section of the south arm of the Mondego estuary. three study sites were chosen, one located inside a muddy Spartina maritima bed while the others where located on bare muddy sediment and bare sandy sediment (See Lillebø et al. 2002a). These pools were studied during 24-hours tidal cycles in July 97 and November 97, respectively in summer and fall, and representing different average temperature, hydraulic conditions, emersion time, plant coverage, and organic content in the sediment (Flindt et al. 2001, Lillebø et al. 2002a, Martins et al. 2002). Nutrient dynamics was followed in the water of each pool, with I-hour periodicity, from its formation until it was submerged again. Flux chambers were placed in the main channel (under day and night situations, July 2001) for comparison of the efflux rates in the low water pools.

In July 97, sediment cores were sampled from each pool and analysed for potential phosphate adsorption capacity ( $\mu$ mol POA-P g' dwt sediment). (See Flindt et al. 1999, 2002). Calculations of the mean phosphate efflux rates ( $\mathrm{mg} . \mathrm{m}^{2} \mathrm{~d}^{\prime}$ ) were performed considering: a) the mean daily efflux rates (day and night) from each type of pool (Lillebø et al. 2002a); b) a visual estimation of the contribution of each type of pool to the estuarine area ( $1.9 \mathrm{~km}^{2} .17 \%$ Spartina, $50 \%$ mud and $33 \%$ sand); c) a visual estimation of the area covered by pools during low tide (40\%); d) the mean efflux rates in July could represent a mean value for spring and summer, and that the mean efflux rates in November could represent a mean value for fall and winter. In the main channel it was assumed that there is no significant seasonal variation.

It is well known that nutrient fluxes are strongly dependent on temperature dynamics, and higher phosphate effluxes in temperate regions are found at elevated temperatures (Asmus et al. 2000). We therefore used, as a preliminary approach. a simple dynamic temperature model to simulate the yearly variation in the phosphate fluxes. The model equations are:

$$
P O_{4} \text { flux actual }=P O_{4} \text { fluxt, }{ }^{*} K\left(\text { tempariw }{ }^{n}\right)
$$

Accumulated $\mathrm{PO}_{4}$ flux $=\mathrm{PO}_{4}$ fluxt+1 $+\mathrm{PO}_{4}$ fluxt

Where the $\mathrm{PO}_{4}$ flux is the measured phosphate flux at a certain temperature $\left(n^{\circ} \mathrm{C}\right), \mathrm{K}$ is temperature dependency constant, while temputum is the simulated phosphate fluxes. The only forcing function was the temperature. Afterward the simulated fluxes becomes numerical integrated so the yearly internal loading, due to the flux dynamics, for the pools becomes simulated. 
Calculations of the phosphate mass efflux $(\mathrm{kg} P)$ were also performed assuming that the mean efflux rates in July could represent a mean value for spring and summer, and that the mean efflux rates in November could represent a mean value for fall and winter. In the main channel it was assumed that there is no significant seasonal variation.

\section{Results}

Loading

Between June 93 and June 94, discharges of dissolved inorganic phosphorus proceeding from the Pranto River occurred mainly between October and April (Fig. 3). This variation is related to precipitation and the needs to balance the water level in rice fields located in the Pranto River valley. The maximum input of dissolved inorganic phosphorous occurred in November $(50.73 \mathrm{Kg}$ ). (Pardal 1998).

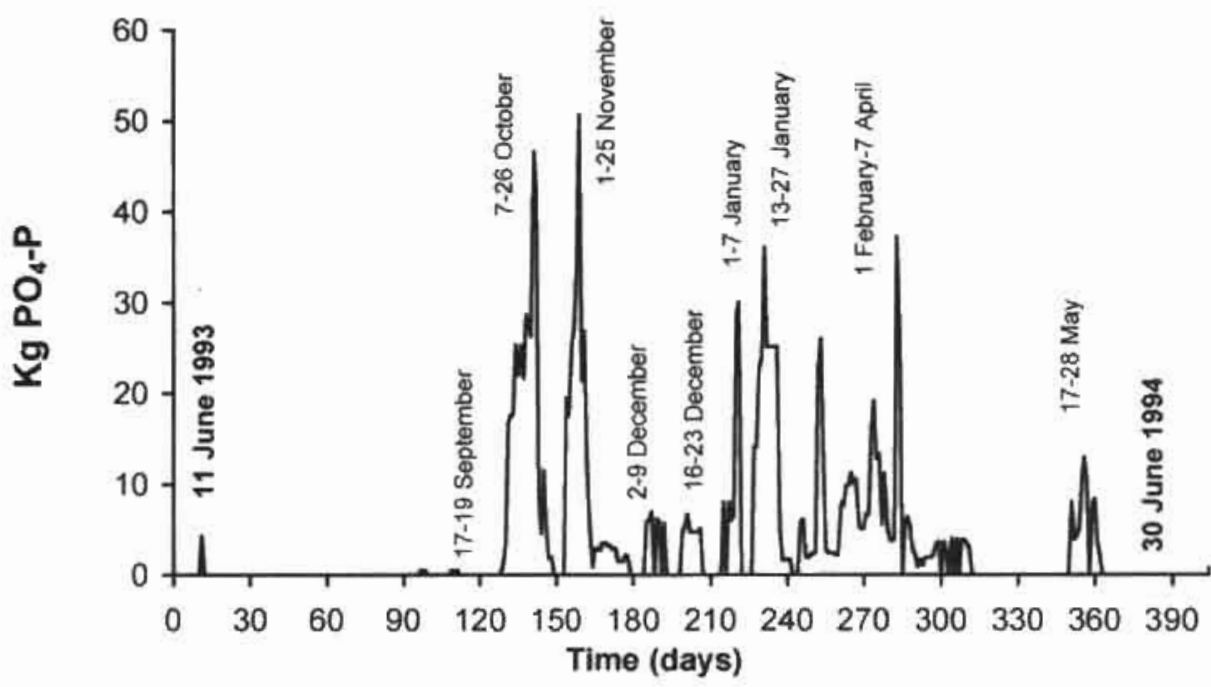

Fig. 3. Monthly unput of dissolved inorganic phosphorus from Pranto River discharge, from june 93 to June 94.

The loading estimates for dissolved inorganic phosphorous (Fig. 4) showed that between June 93 and June 94, the estuary was exporting phosphorous almost all year around except for a short period, from late winter (February) to early spring (April). when phosphorous uptake was observed in the system (Pardal 1998). 


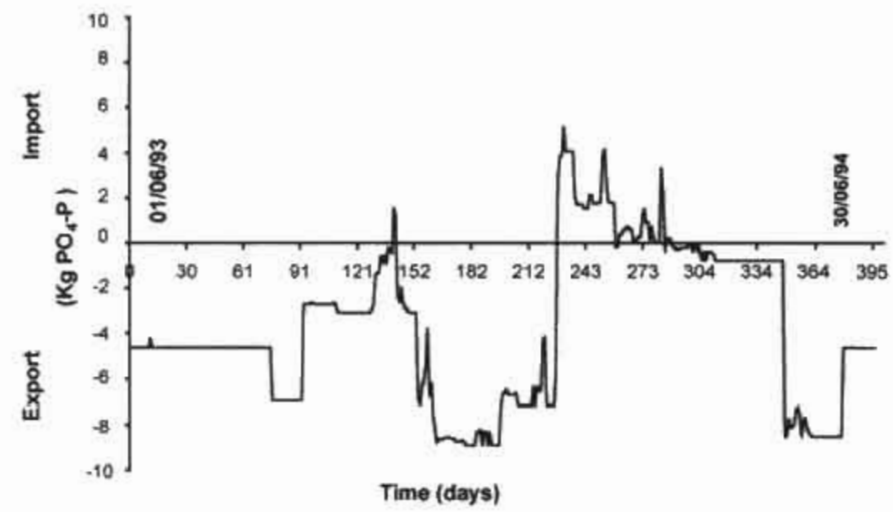

Fig. 4. Monthly mass balance of inorganic dissolved phosphate in the south arm, from june 93 to june 94. Positive values mean consumption within the system and the negative values represent release from the system.

\section{Field monitoring program}

Results show a clear seasonal variation of dissolved inorganic phosphorus in the south arm of the estuary (Fig. 5), with higher concentrations recorded always in August/September (values varied between 0.08 and $0.14 \mathrm{mg} \mathrm{l}^{-1}$ ) and lowest during winter (always close to $0.016 \mathrm{mg} \mathrm{H}^{-1}$ ). Moreover, if we consider only data between June 93 and June 94 , it is possible to see that dissolved inorganic phosphorous proceeding from the Pranto River discharge did not increase the concentration at the system level.

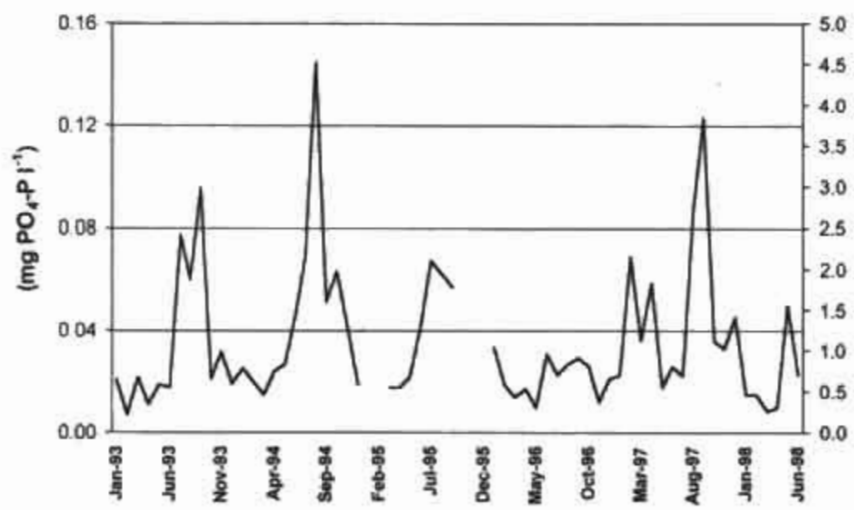

Fig. 5. Monthly concentration of dissolved inorganic phosphorus in the south arm, from January 93 to June 98. 
Data from January 93 to June 98 showed seasonal variations of temperature and salinity, and some inter-annual variation especially regarding salinity (Fig. 6). During summer, water temperature varied between $23^{\circ} \mathrm{C}$ and $28^{\circ} \mathrm{C}$, and during winter it was always close to $10^{\circ} \mathrm{C}$, during the day. Salinity seasonal variation was basically a function of precipitation and the fresh water input from the Pranto River.Values were usually higher than 25 in the summer and lower than 15 in the winter (Fig. 6). Moreover, during a dry hot summer salinity could reach values of 35 (e.g. September 97), and during rainy winter periods salinity values could be lower than 5 (e.g. January 96 and December 97).

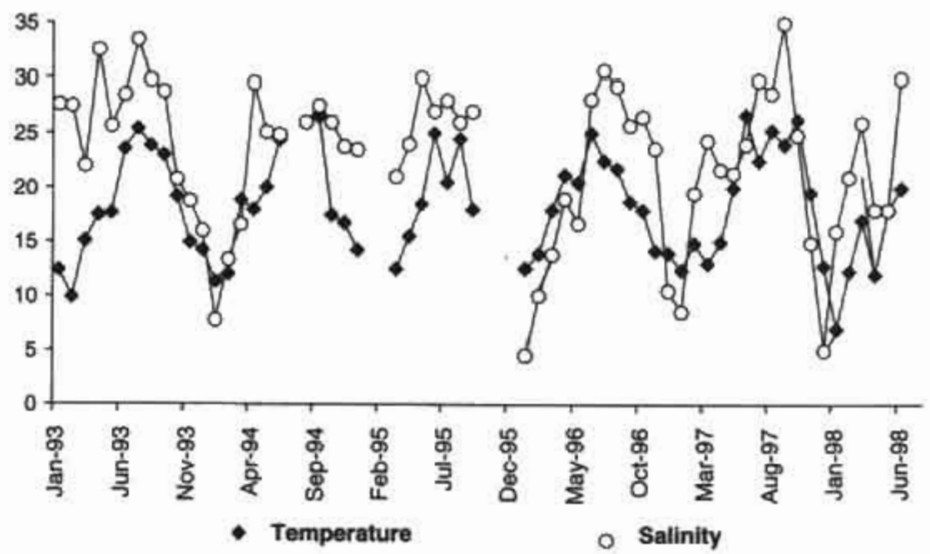

Fig 6. Monthly measurements of temperature and salinity in the south arm, from january 93 to June 98 .

Intertidal pools study

Considering the mean daily efflux rates (day and night) from the muddy bare bottom pool, there was a clear seasonal variation of the efflux rates, with higher $P$-effluxes during summer and lower during fall (Fig. 7). In the Spartina covered pool and in the sandy pools, this seasonal variation is not visible, and in the main channel the efflux rates are comparatively low, and we assumed that there is no seasonal variation (Fig. 7).

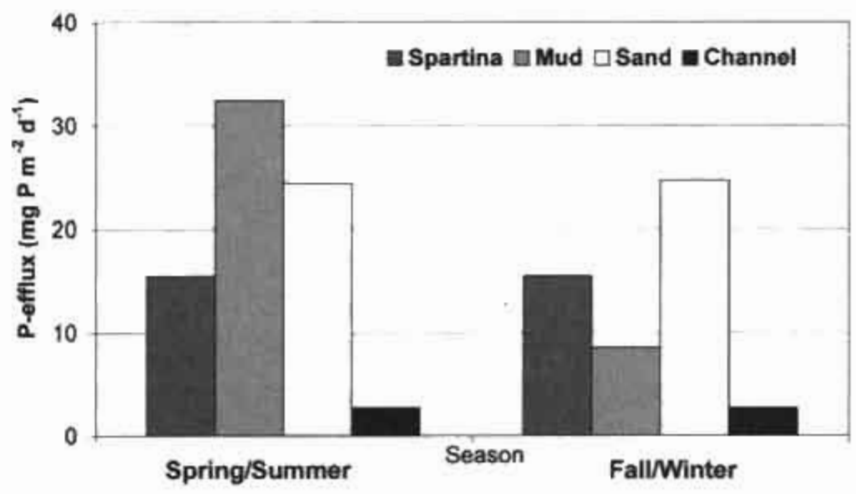

Fig. 7. Seasonal variation of phosphate mean efflux rates ( $\left.\mathrm{mg} \mathrm{PO}+\mathrm{P} \mathrm{m}^{-1} \mathrm{~d}^{\prime}\right)$ at each pool type and the main channel. 
This seasonal variation is closely related with temperature and redox state of the sediment/water column inter-phase, and differences among pools appeared to be related to pool plant coverage and organic matter content in the sediment. Adsorption/desorption isotherms were also studied in July 97 showing that the muddy Spartina thizosphere had highest adsorption capacity (Fig. 8) with $4.5 \mu \mathrm{mol}$ PO.-P mol' dwt. sediment, while in bare muddy areas, at the same sediment depth, the adsorption capacity was only $2.6 \mu \mathrm{mol} \mathrm{PO}_{4}-\mathrm{P}$ mol $^{-1}$ dwt. sediment (Flindt et al. 1999, 2002). In bare sandy sediment the adsorption capacity was clearly lower than in muddy sediments, reaching $0.97 \mu \mathrm{mol} \mathrm{PO}_{4}-\mathrm{P} \mathrm{mol}^{-1}$ dwt. sediment (Flindt et al. 1999. 2002).

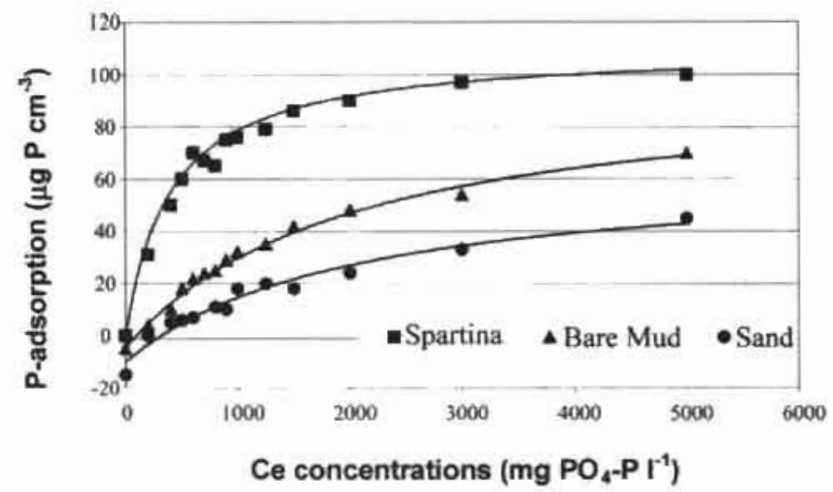

Fig. 8. Sediment phosphate adsorption capacity (P-sorption fitted to Langmuir exp.) at the three study sites.

As the P-efflux seasonal variation was only clear for the muddy bare bottom pools, we simulate the internal loading of phosphate based on a temperaturedependent model, as a preliminary approach (Fig. 9). Despite cautions in interpreting this simulation, due to the lack of points for the calibration of the model, it express an increase of phosphate efflux during the warmer periods (spring and summer) and a decrease during fall and winter.

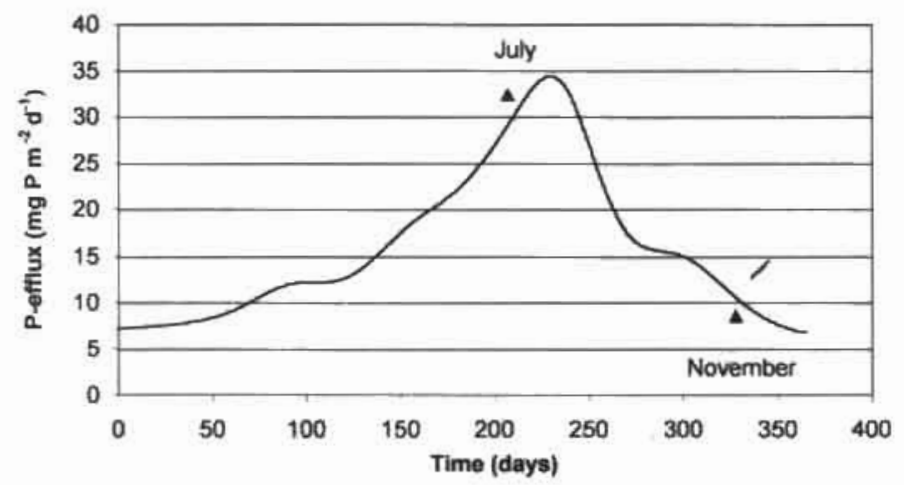

Fig 9. Simulation of the yearly variation in phosphate fluxes, in pools located in the bare bottom muddy areas of the estuary. 
Phosphate dynamics at the system level

Calculations of the phosphate net effluxes ( $\mathrm{kg} \mathrm{P}$ ), assuming that july data could represent summer and spring and that November data could represent fall and winter, suggest a strong contribution of the bare bottom muddy pool to the whole system internal phosphate loading ( $F i g$ 10), and especially during the warmer periods. The Spartina covered pool had comparatively a lower effect on the internal phosphate loading than the sandy covered pool, but higher than the channel (Fig. 10).

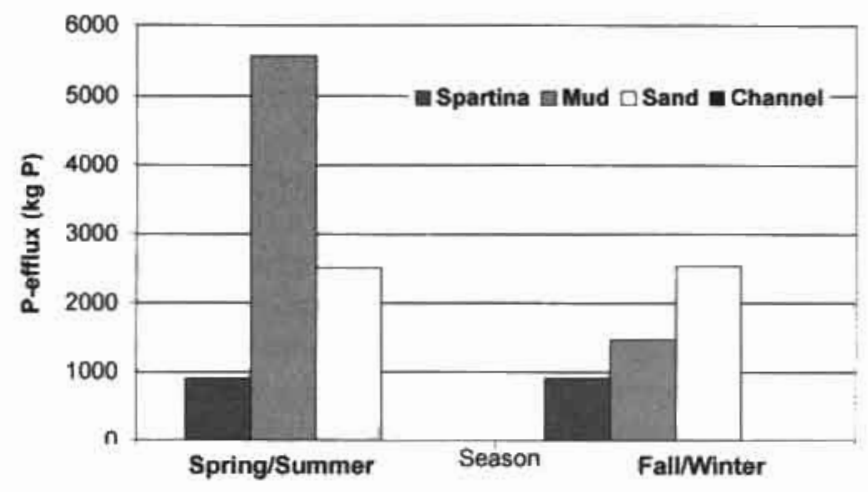

Fig 10. Yearly net efflux of phosphate (kg P) for each type of pool and the main channel.

This preliminary approach show that the phosphate efflux from the pool system level can contribute with several tons (13.8 t, by these calculations) of dissolved inorganic phosphorus to the net internal loading, which corresponds to the previous loading calculations for the estuary.

\section{Discussion and conclusions}

The annual mass balance of dissolved inorganic phosphorous shows that the estuary is exporting 14 ton $y^{-1}$, but also that the system is retaining most of the dissolved inorganic phosphorus during late winter and early spring (Pardal 1998). Such retention probably results from an enhancement of primary producers growth during this period. namely from phytoplankton, macroalgae (e.g. Enteromorpha sp.) and rooted macrophytes (e.g. Zostera noltii, Spartina maritima and Scirpus moritimus) (e.g Pardal 1998, Lillebø 2000. Martins 2000). On the other hand, the Pranto River discharges were more significant between October and April (Pardal 1998), but during this period there was not an increase in the concentration of dissolved inorganic phosphorous at the system level. Therefore, the south arm of the Mondego estuary may be functioning as a sink of phosphorous during winter and the growing season, but also as a source of phosphorous to the estuarine plume zone or even to open coastal waters during summer.

Values of dissolved inorganic phosphorus concentration in the south arm of the estuary were higher in summer, and other authors have also noticed the phenomena of increase phosphorus concentration during this period (Hinga 1990, Tian et al. 1993, 
Valiela 1995) and under anoxic conditions (Sfriso 1988, Perttilä et al. 1995). Moreover, the temperature and the oxic state of the sediment may be very important to the efflux of phosphorus due to an intensification of anaerobic decomposition pathways of organic matter (Forja et al. 1994 in Falcão and Vale, 1998).

Results obtained may express the inorganic dissolved phosphorus adsorption and consumption, but the question remains: How does the south arm of the Mondego estuary supply the increase of inorganic dissolved phosphorus concentration during late spring and summer, and consequently its export from the system?

In intertidal systems, sediments get exposed to air and subsequent drying conditions during ebb tide, and it has been shown that under this desiccated/oxidation conditions sediments have a lower affinity for phosphorus than submerged sediments (Baldwin 1996 in Mitchell and Baldwin 1998). Phosphorus dynamics in sediments is strongly influenced by cycles of iron and sulphur (Sundby et al. 1992), and the lower phosphorus release under desiccated conditions may be explained by three main factors: drying and ageing of minerals with which phosphorus is associated, (particularly iron hydroxides), carbon limitation as a result of drying, and by the shift in bacterial community structure, specially the loss of viable sulphate-reducting bacteria (Mitchell and Baldwin 1998). However, it has been showed that these elements (iron and sulphur) can be very reactive when flooding water spreads over the sediment (Caetano 1977 in Falcão and Vale 1998). Moreover, as a result of the reduction of the insoluble ferric hydroxides compounds to more soluble ferrous hydroxides compounds, under flooded conditions sediments have many more sorption sites than under drained conditions (Patrik 1992). So, in the presence of bio-reducible iron, the redox state of the sediment and the amount of phosphorus in pore-water or water column determine whether phosphorus is released or absorbed. Furthermore, in intertidal estuaries, such as the Mondego estuary, the low water intertidal pools may cover $30-40 \%$ of the total estuarine area. Within these pools, physic and chemical conditions usually change quite fast (Flindt et al. 2002. Lillebø et al. 2002a, Martins et al. 2002), in comparison to the main water-body, reaching very high water temperature and low oxygen concentrations, especially during spring night ebb tides. During this period, and in consequence of respiration by microfauna, meiofauna and macrofauna, these pools may become anoxic, when microphytobentos, macroalgae and rooted macrophytes are unable to compensate the oxygen consumption. Under such conditions, the adsorbed phosphate can be released to the pore-water and an increased efflux from the sediment to the water column may occur (Patrik 1992), 298 depending on whether the phosphate concentration in the bottom water is lower or higher than the equilibrium concentration in the pore water (Sundby 1992).

Considering the fact that sediments constitute a major source of phosphorous supply for macrophytes, during the day, there might be a certain competition between two processes: Spartina maritima increased adsorption capacity and the efflux from the sediment In fact, under more oxygenated conditions, like the ones surrounding plants thizosphere, the ferrous iron precipitates as ferric hydroxides, removes dissolved phosphate by readsorption to oxidized iron compounds (Berner and Berner 1996, Anderson and Ring 1999). 
The highest mean phosphate effluxes occurred in summer with a clear contribution of the bare bottom muddy areas, which may be explained by the organic matter content, and the P-sorption capacity of the plants (Flindt et al. 2002, Lillebø et al. 2002a).

Taking into account these preliminary approach, we may consider that phosphorus release in intertidal pools during low-water periods appears to represent an important contribution to the increase concentration of dissolved inorganic phosphorus in the main water-body, and that this process can be particularly significant during the warm periods. In fact, our results suggest that, in absence of external sources, the daily phosphate efflux from the pools level is able to support the main water-body phosphate concentration. Although, we are still not able to quantify exactly the relatively contribution of each type of pool, it is clear that the intertidal pools system, by providing a dramatically increase of temperature conditions, stimulates $P$ mineralisation and P-desorption and thereby the efflux of phosphate. Nevertheless, these results should be regarded as a preliminary approach for two main reasons: the lack of sampling points to calibrate the simulated fluxes, as well as the yearly net efflux of phosphorus; and due to the fact that Scirpus maritimus, annual dynamics has not been taken into consideration. Although from July until December only bellow-ground part of the plants persists (Lillebø 2000, Lillebø et al. 2002b). So, further research is being provided in order to accurate these results.

\section{Acknowledgements}

The present work was supported by the Programme MAST II (MAS 2 CT 92 0036), by the WET-project, (Wetland Ecology and Technology), funded by the European scientific TMR program, (TMR) (ERB 406I PL 95-0832), by the F-ECTS project founded by the European Scientific MAST 3 program inside the ELOISE frame, and by the Praxis XXI program (Portugal) through a PhD grant (BD/9290/96). The authors would like to thank the Freshwater Biological Laboratory, University of Copenhagen, Denmark, for the support to conduct this study.

\section{References}

Anderson, F,, and P, Ring 1999, Companson of phosphorus release from litoral and profundal sediments in a shallow, eutrophic lake. Hydrobiologia 408/409: 175-183.

Asmus, R.M.M. Sprung and H. Asmus. 2000. Nutrient fluxes in intertidal communities of a south European lagoon (Ria Formosa) - similarities and differences with a northern wadden sea bay (Syl-Rørnø bay). Hydrobiologia. 436: $217-235$

Berner, E.K and R Bemer 1996. Margin marine environments, estuaries in Global Environment, water, air and geochemical cycles. pP 284.311.

Falcāo, M. and C.Vale 1998. Sediment-water exchanges of ammonium and phosphate in intertidal and sutidal areas of a mesotidal coastal lagoon (Ria Formosa). Hydrobiologia. 373/374: 193: 201.

Findt, M.R, L Kamp-Nielsen, I.C. Marques, MA. Pardal, M. Boca, G. Bendoricho, S.N. Nielsen and S.E. Jørgensen 1997. Description of the three shallow estuaries: Mondego River (Portugal), Roskilde Fjord (Denrnark) and the Lagoon of Venice (italy). Ecol. Model. 102: 17-31.

Flindt, M.R. MA. Pardal, Lillebo. A.I. Martins I. and J.C. Marques. 1999. Nutrient cycling and plant dynamic in estuaries: a brief review. Acta Oecol. 20 (4) 237-248. 
Flindt. M, R, MA. Pardal, Al. Lillebø, L. Martins and JM. Oliveira 2002 Nutrient dynamics in the intertidal pools of the Mondego Estuary. I - Nutrients sources, sediment profiles, mineralisation and adsorption dynamics. Aquatic Ecology of the Mondego River Basin. Global importance of local experience. (This volume)

Hinga, KR 1990. Alteration of phosphorous dynamics during experimental eutrophication of endosed manne ecosystem. Mar.Pollut. Bull. 21 (6): 275-280.

Lillebo. A.l. 2000. The effect of salt marshes plants on the nutient dynamics in the Mondego estuary (Portugal). PhD Thesis, FCT-University of Coimbra, 159p.

Lillebe A.I. M.R. Findt. M.A. Pardal. L. Martins, J.M. Neto and J.C. Marques 2002a. Nutrient dynamics in the intertidal pools of the Mondego Estuary. II - Seasonal efflux of PO- $\mathrm{P}$ and $\mathrm{NH}_{4}-\mathrm{N}$ in bare bottom and vegetated pools. Aquatic ecology of the Mondego River Basin. Global importance of local experience. (This volume)

Lillebø A.I., J.M. Neto, M.A. Pardal, M.R. Findt and J.C. Marques 2002b. The role of Spartina mantima and Sorpus mariomus to sediment pore-water profiles, and possible implications to the Mondego estuary nutrient dynamics. Aquatic ecology of the Mondego River Basin. Global importance of local experience (This volume)

Marques, J.C.. MA. Pardal. S.N. Nielsen and S.E Jørgensen 1997. Analysis of the properties of exergy and biodiversity along an estuarine gradient of eutrophication. Ecol. Model. 62:155-167.

Marques, J.C. MAS, Graça and MA. Pardal 2002. Introducing the Mondego River Basin. Aquatic ecology of the Mondego River Basin. Global importance of local experience. (This volume)

Martins, L.C. 2000. Green macroalgae and seagrasses in a shallow eutrophic estuary, the Mondego Estuary: Dynamics, controlling factors and possible evolutionary scenarios. PhD Thesis. FCT-University of Coimbra. 140p.

Martins L. M.A. Pardal, A.1. Lillebø, M.R. Findt and J.C. Marques 2002. Hydrodynamics as a major factor controlling the occurrence of green macroalgae blooms in a eutrophic estuary. A case study. Estuar. Coast. Shelf Sci. 52:165.177.

Martins I. M.R Findt. M.A. Pardaj, A.I. Lillebø. J.M. Oliveira and J.C. Marques 200I. Nutrient dynamics in intertidal pools of the Mondego estuary. III - The importance of nutrient effluxes to macroalgal growth (Enteromorpho sp.). Aquatic ecology of the Mondego River Basin. Global importance of local experience. (This volume)

Mitchell, A and D.S. Baldwn 1998. Effects of Desiccation/oxidation on the potental for bacterial mediated P release from sediments. Limnol. Oceanogr. 43 (3): $481-487$.

Pardal, MA. 1998 Impacto da eutrofização nas comunidades macrobentónicas do braço sul do estuánio do Mondego (Portugal), PhD Thesis. University of Coimbra. $315 \mathrm{p}$.

Pardal, MA, J.C. Marques, L. Metelo, A L. Lillebø and Flindt, M. R. 2000. Impact of eutrophication on the life cycle, population dynamics and production of Ampithoe valido (Amphipoda) along an estuanne spatial gradient (Mondego estuary. Portugal). Mar, Ecol. Prog Ser. 196:207-279.

Patrick. Ir and Wm. H. 1992. Phosphorus biogeochemistry of wetlands In Phosphorus, Life and Environment. From research to application. Gand, Belgique, pp: 199-205.

Pertulă M. L Niemistö and K Măkelă 1995. Distribution. development and total amounts of nutrients in the Gulf of Finland. Estuar. Coast. Shelf Sci. 41: 345-360.

Pettine M. T. la Noce, G. Macchi, R Pagnotta and A Puddu 1983. Factors affecting the conservation of nutrents in estuarine waters of the River Tiber. Chemistry Ecol. 1:293-309.

300 Sfriso, A. B. Pavoni, A. Marcomini and A.A. Orio 1988. Annual variation of nutrients in the Lagoon of Venice Mar. Pollut Bull, 19 (2): 54-60.

Sundby. B., C. Gobeil, N. Silverberg and A. Mucci 1992 The phosphorus cycle in coastal marine sediments. Limnol. Oceanogr. 37(6): $1129-1145$.

Standard Methods 1995. For the experimentation of water and wastewater. 19th ed. Andrew D. Eaton. Lenore S. Clesceri and Amold E Greenberg. America Public Health Association, Washington, USA.

Strickland, J.D.H. and T.R. Parsons 1968. A practical handbook of seawater analysis. Fisheries Research Board of Canada, Ottawa. Bulletin 167,311 p.

Tian, RC. FX. Hu and M. Martin 1993. Summer nutrient fronts in the Changiang (Yantze River) estuary Estuar. Coast Shelf Sci. 37: 27-41.

Valiela. I. 1995. Marine Ecological Processes. 2nd ed. Springer-Verlag New York, Inc: 425-433. 

Série

Investigação

$\bullet$

Coimbra

Imprensa da Universidade

2002 